\title{
膝関節鏡視下手術の経験
}

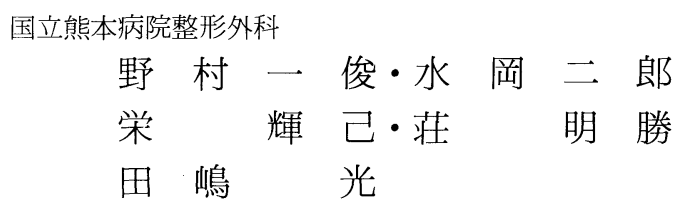

\section{Arthroscopic Surgery on the Knee Joint}

\author{
by \\ Kazutoshi Nomura, Jiro Mizuoka, Terumi Sakae, Katsuaki So \\ and Hikaru Tajima \\ Department of Orthopaedic Surgery, National Kumamoto Hospital.
}

\begin{abstract}
We performed arthroscopic surgery on the knee joints of 82 patients from June 1981 to April
\end{abstract} 1984.

Meniscectomy was performed in 41 cases. (medial meniscectomy; 14 cases; lateral meniscectomy: 25 cases, of which 16 cases were discoid meniscus; medial, and, lateral meniscectomy : 2 cases.)

Synovectomy was performed in 15 cases. (rheumatoid arthritis : 9 cases; pyogenic arthritis : 3 cases; unknown : 3 cases.)

Shelf operation was performed in 10 cases.

Joint mobilization was performed in 6 cases.

Removal of loose body was undertaken in cases and other operations were performed in 5 cases.

We used Watanade $21 \mathrm{CL}$ and CLM arthroscope and performed surgery by two point method in the majority of cases of meniscectomy.

But posterior horn of medial meniscus was cut by the three point method in some cases.

At popliteal tendon portion, the rest of the meniscus after partial meniscectomy was frequently unstable, especially in the case of complete discoid meniscus.

There were no technical problems in the shelf operations.

Joint mobilization was a simple and useful method for treating the stiff joint if performed within 2 or 3 months after the previous operation.

\section{はじめに}

関節鏡視下手術は, 少ない手術侵襲，早期の社会復 帰，スポーツ復帰が可能であるなどの大きな利点があ る反面，手術操作には，かなりの習熟を要し，また術 者, 器械設備等にて, その手技も異なり, 多くの技術 的問題がある. 今回, 昭和 56 年 6 月より昭和 59 年 4 月 までに経験した82例の鏡視下手術について検討したの で報告する。

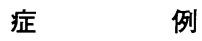

半月切除術 41 例，滑膜切除術15例，棚手術10例，関
節内療着剝離術 6 例，関節内遊離体摘出術 5 例，その 他 5 例である。(表 1 )

1. 半月切除術

内側半月切除 14 例, 外側半月切除 25 例, 内外側半月 切除 2 例で, 内側では14例中 8 例がバケツ柄断裂で, 外側では25例中16例が円板状半月である．円板状半月 16 例中 8 例は完全型円板状半月である. 内外側切除例 は，共に陳旧性前十字勒帯断裂（欠損）を伴っていた が, 半月切除のみ行い経過観察中である。(表 2). 麻 酔は原則として硬膜外麻酔または腰椎麻酔を行い，原 則として駆血帯を使用した．関節鏡は渡辺式21号 CL 及びCLM 直視鏡を用いた。手術器械は，尖端鈍軽度 
表 1 手術症例

\begin{tabular}{|c|c|}
\hline Meniscectomy & 41 \\
\hline Synovectomy & 15 (bilateral 3) \\
\hline Shelf Surgery & 10 (bilateral 2) \\
\hline Joint Mobilization & 6 \\
\hline Removal of Loose Body & 5 \\
\hline Fat Pad Excision & 1 \\
\hline Chorda Surgery & 1 \\
\hline Lateral Release & 1 \\
\hline Drilling & 1 \\
\hline Meniscorisis & \\
\hline Reduction of Fracture & 1 \\
\hline
\end{tabular}

(Jun. 1981-Apr. 1984)

\section{表 2 半月切除術}

\section{MENISCECTOMY}

med. meniscectomy

bucket handle

flap

longitudinal

horizontal

lat. meniscectomy

discoid meniscus (complete 8)

flap

longitudinal

bucket handle

transverse

med. and lat. meniscectomy

med. flap tear

lat. transverse tear

ACL rupture

med. bucket handle tear

lat. longitudinal tear

ACL rupture

及び外側膝蓋上部より鋭匙針子にて切除する方法をと っているが，RAの3 例に水腫の再発をみた他は一応 満足すべき結果を得ている. 後療法は半月切除に準じ ており術後疼痛もほとんどみられなかった。棚手術は， 外側膝蓋上部より関節鏡を，外側膝蓋下よりハサ之ま たは鋭匙鉗子を入れ，切除又は切離を施行した。(表

$3)$

表 3 滑膜切除術及び棚手術

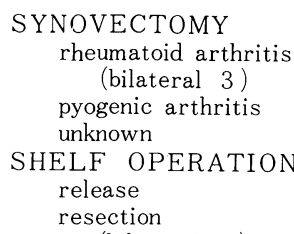

\section{5}

9

3

10

(bilateral 2)

3 . 関節内癒着剝離術

脛骨顆部骨折術後 2 例, 勒帯断裂術後 2 例, 脛骨高 位骨切り術後 1 例, 化膿性関節炎後 1 例, 計 6 例に施 行した。（表 4) 術前に関節造影にて関節内の癒着状態 を把握しておき, 上囊部，ついで内外側谷部の癒着を 切離した後徒手的に膝を屈曲する. 術後経過期間の長 い脛骨高位骨切り術後の症例を除き良好な結果を得て いる。

\section{表 4 関節内癒着剝離例}

わん曲の形成用ハサ之と鋭匙鉗子及びバスケットパン チを主に用い，原則として 2 点法で行った。切除範囲 は, 最少限の部分切除とし, 円板状半月は亜全摘を原 則とした。後療法は術後 1 日目より松葉杖歩行を許可 し大腿四頭筋訓練を行わせる．全荷重力疼痛なく可能 となれば松葉杖を除去する. 通常術後 $8 \sim 9$ 日で退院 を許可している。なお， 円板状半月覀全切除，全切除 例にはバー付サポーターを術後 1 ケ月間装着させてい る. 術後合併症には関節血腫, 関節水腫, 手術瘢痕部 の疼痛などが少数例にみられたが, 特に大きな問題と はなっていない，再手術が 1 例あり，外側円板状半月 で切除不足であった。

2 . 滑膜切除術及び棚切切除術

滑膜切除術は，15例18関節に施行した。内外膝蓋下

$$
\text { JOINT MOBILIZATION }
$$
1. 61 Y. female high tibial osteotomy

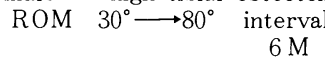
2. $54 \mathrm{Y}$. female tibial condyle fracture post. ope.
3. $56 \mathrm{Y}$. male tibial condyle fracture post. ope.
4. $42 \mathrm{Y}$. female $\mathrm{MCL}, \mathrm{ACL}$ rupture post. ope. $\mathrm{ROM} \quad 70^{\circ} \longrightarrow 130^{\circ} \quad 2.5 \mathrm{M}$
5. 52 Y. female MCL, ACL rupture post. ope.
ROM $60^{\circ} \longrightarrow 140^{\circ} \quad 2.5 \mathrm{M}$
6. 56 Y. female pyogenic arthritis



膝関節鏡視下手術の手技は，半月切除術に集約され ていると言ってよい. 半月切除術は把持鉗子を使用す 
る 3 点法と，使用しない 2 点法に分けられる. 陳は 2 点法の利点を，切除範囲が過大とならないとと，助手 による器械操作が必要ないとと, 視野がふさがらない ことをあげているが，最大の利点は助手による器械操 作が必要でないととであろう。われわれも原則として 2 点法で行っており，大部分の手術は本法で可能であ る. しかし内側半月バケツ柄断裂等で中央部へ転位し た柄部後方の切離は 2 点法では難しい場合が多く，前 方を先に切離し，てれを鉗子で引き出しながら後方を 切離した方が容易である. 円板状半月は，断裂部位， 厚さ等にて切除範用，方法が問題となる．亜全切除を 原則としているが，断裂が及んでいなければ，かなり の範囲を残すこともある.（図1) 厚さか渄常に厚い場



図 1 外側円板状半月切除例

合は全切除を行った．切除方法は初期には，enbloc に 近い切除を試みていたが，最近は前方部分より視野を 広げながら数個に分けて切除しており，ての方が技術 的に容易で，時間的にも短縮されており，enbloc 切除 にあまりこだわらない方がよい，外側半月では膫筒筋 腱部が問題となる場合が多い。この部に断裂が及んで いたり，残存部が不安定な場合は切除せざるを得ない が，不用意に切除を進めて同部を損傷し切除せざるを 得なくなることがあるので注意を要する。(図2)半月 周辺部は血行があり半月縫合の適応がある場合があり， 最近半月縫合術が鏡視下に行われているが，鏡視下手 術には半月の前節から中節の綐断裂が最もよい適応と 考えられる.われわれも一例仁鏡視下半月縫合術を試 みた。本例は脛骨外顆陌没骨折及び外側半月前節より 中節部までの縦断裂がみられ，陮没骨折を鏡視下に整
復，骨移植を行い同時に鏡視下にナイロン系にて縫合 を行った。(図3)
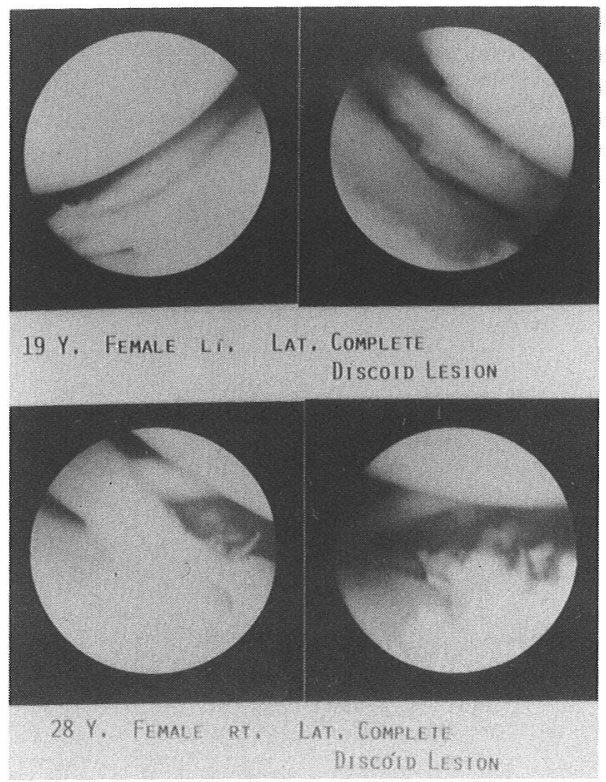

図2 上段：膝窩笳腱部が安定している例 下段：除窩筋腱部が不安定で切除せざるを 得なかった例

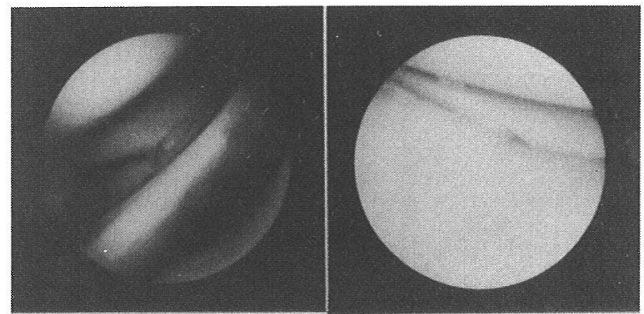

35 y. Male Lt. Lat. Tibial Condyle fracture Lat. Meniscus Longitudinal tear

図 3 半月縫合施行例

鏡視下滑膜切除術について，有富は高周波切除鏡に よる良好な成績を報告しているが，鋭匙鉜子による多 方向切除法が一般的に行われている，鋭匙鎮子による 切除では, 切除を進めていくと，しだいに滑膜が浮腫 状となり切除しにくくなってくる場合があり，滑膜増 殖の著しい場合は切除にかなりの時間を要する。しか 
し術後の疼痛は少なく, 後療法を特に要さず, 患者の 身体的社会的負担の軽減は大きい.

棚手術は，手技的には，問題は少ないが，正確な診 断及び，手術に際し関節包を傷けないよう注意が必要 である。

関節内癒着の強い症例は, 関節鏡挿入時に関節軟骨 の損傷をきたす危険性が高く，関節鏡の適応外となる 場合が多いが, 膝蓋大腿関節に癒着がなければ, 関節 鏡の捜入に問題はなく, 鏡視下に線維性癒着を鋭的に 剝離していくことが可能である. 林酔下徒手矯正に比 し非暴力的で, 術後疼痛も少ない. 筋の短縮等関節外 因子の少ない術後 2 〜 ケ月の拘縮例に最もよい適応 があると考えている。

\section{ま と め}

鏡視下半月切除術, 滑膜切除術, 棚手術, 関節内癒 着剥離術について検討を行った。

鏡視下手術は, その技術的問題が克服されれば, 極 めて有用な手術法である.

\section{参 考文 献}

1) 有富 寛: 高周波電流切除鏡による膝関節鏡視下手術 の展開. 臨整外, 19:28-35, 1984.

2) 陳 永振：関節鏡視下手術の検討. 臨整外, 19:7378,1984

3）藤沢義之ら：外来鏡視下手術. 臨整外, $19: 37-48$, 1984.

4) 池内 宏: 私の行っている半月板鏡視下手術. 手術, 37:965-972, 1983.

5) 伊藤一忠 : 膝関節鏡視下手術の為の診断法. 臨整外, $19: 65-71,1984$.

6）木村雅史ら：関節鏡視下半月切除術の手術成績. 臨整 外. $19: 55-64,1984$.

7) 守屋秀繁：鏡視下半月切除術の術式および術後成績の 検討. 臨整外, $19 ： 49-54,1984$. 